Macedonian Pharmaceutical Bulletin, 66 (Suppl 1) 177 - 178 (2020)

Online ISSN 1857 - 8969

UDC: 637.12.06:615.33

DOI: $10.33320 /$ maced.pharm.bull.2020.66.03.088

Short communication

\title{
Determination of fluoroquinolone antibacterial residues in milk by LC-MS/MS method
}

\author{
Gjylai Alija ${ }^{1}$, Zehra Hajrullai-Musliu², Risto Uzunov $^{2}$, Drita Havziu ${ }^{3}$, \\ Arlinda Haxhiu-Zajmi ${ }^{3}$, Edita Alili-Idrizi ${ }^{3}$, Agim Shabani ${ }^{3}$ \\ ${ }^{1,3}$ Department of Pharmacy, Faculty of Medical Sciences, University of Tetova, \\ St. Ilinden 1200, Tetovo, North Macedonia \\ ${ }^{2}$ Faculty of Veterinary Medicine, Ss. Cyril and Methodius University, \\ Lazar Pop-Trajkov 5/7, 1000 Skopje, North Macedonia \\ ${ }^{3}$ Department of Chemistry, Faculty of Natural Sciences and Mathematics, University of Tetova, \\ St. Ilinden 1200, Tetovo, North Macedonia
}

\section{Introduction}

Fluoroquinolones (FQs) are a group of broadspectrum antibiotics, derived from nalidixic acid. They are widely used to treat or prevent bacterial infections in veterinary and aquatic medicine. Also they can use as growth promoters. These residues may cause bacterial resistance, allergic hypersensitivity and toxicity effect (Junza et al., 2010). Due to their side effects in public health, the European Union has established maximum residue levels (MRLs) for most antibiotics in milk and animal tissues. Various analytical methods have been reported for analysis of FQs in food producing animals including screening and confirmatory methods. LC-MS/MS method have high sensitivity and selectivity which can allow for the simultaneously separation and confirmation of many antibiotics in a single run (Alija et al., 2016; Berendsen, 2013; Uzunov et al., 2019). The aim of this study was to develop and validation of LCMS/MS method for determination of FQ drug residues Enrofloxacin (ENR) and Ciprofloxacin (CIP) in bovine milk and analysis of real bovine milk samples for detection of these residues.

\section{Materilas and Methods}

Sample collection

In this study were analyzed a total of 250 bovine milk samples, collected from Macedonian farmers during 2016-2019.

\section{Standards, chemicals and reagents}

ENR, CIP, methanol, acetonitrile, water (LC-MS grade), trichloroacetic acid (TCA), disodium hydrogen phosphate dehydrate, disodium salt of ethylene diamine tetraacetic acid, formic acid, sodium chloride, citric acid monohydrate.

\section{Preparation of standards}

Individual stock standard solutions of $1.0 \mathrm{mg} / \mathrm{mL}$ were prepared in methanol. The range of the calibration curve was from 10 to $150 \mathrm{ng} / \mathrm{mL}$.

\section{Sample preparation and extraction procedure}

On $5 \mathrm{~mL}$ of milk was added $2 \mathrm{~mL}$ of $20 \%$ trichloroacetic acid and the samples were shaken for $5 \mathrm{~min}$. After that, $20 \mathrm{~mL}$ of Mcllvaine buffer were added and samples were centrifuged at $4000 \mathrm{rpm}$,

\footnotetext{
*gjulai.alija@unite.edu.mk
} 
$20 \mathrm{~min}$, at $+4{ }^{\circ} \mathrm{C}$. The supernatant was immediately applied to an SPE cartridge (Oasis HLB, 3 cc, 60 $\mathrm{mg}$ ), previously activated with $3 \mathrm{~mL}$ of methanol and $2 \mathrm{~mL}$ of water, washed with $4 \mathrm{~mL}$ of water, eluted with $3 \mathrm{~mL}$ of methanol. The samples were evaporated to dryness under stream of nitrogen at $35^{\circ} \mathrm{C}$. The dry residue was reconstituted with 500 $\mu \mathrm{L}$ of the mobile phase and filtered on a $0.22 \mu \mathrm{m}$ microfilter. Into LCMS/MS system injected $10 \mu \mathrm{L}$.

\section{Chromatographic conditions}

The compounds were separated at $40{ }^{\circ} \mathrm{C}$ using Kinetex ${ }^{\circledR} \mathrm{C} 18$ column $(1.7 \mu \mathrm{m}, 50 \times 2.1 \mathrm{~mm})$. The flow rate was $0.4 \mathrm{~mL} / \mathrm{min}$ and total run time was 13 min. Mobile phase A was water with $0.1 \%$ formic and mobile phase $\mathrm{B}$ was acetonitril with $0.1 \%$ formic acid.

\section{MS/MS conditions}

The MS/MS measurements were performed with triple quadrupole mass detector. For identification and quantification of the residues were used positive electrospray ionization (ESI+) mode and the ions were monitored in the multiple reaction monitoring (MRM) mode.

\section{Method validation}

Validation of the method was performed according to Commission Decision 2002/657/EC. Linearity, decision limit $(\mathrm{CC} \alpha)$, detection capability $(\mathrm{CC} \beta)$, accuracy and precision was determined.

\section{Results and discussion}

Each individual standard with a concentration of $10 \mu \mathrm{g} / \mathrm{mL}$ were directly infused into the MS/MS detector for determination of precursor and product ions. Also, fragmentary voltage and collision energy for each standard were optimized. Chromatographic separation providing satisfactory resolution with retention times between $3.43 \mathrm{~min}$. (CIP) and 4.75 min (ENR). $\mathrm{Na}_{2}$ EDTA-Mcllvain buffer and TCA solvents were found to be sufficiently for protein precipitation, which provided acceptable recoveries.

The linear regression analysis showed good correlation with $\mathrm{R}^{2}$ from 0.9817 for ENR and 0.9946 for CIP. The CC $\beta$ values ranged from $120.51 \mathrm{ng} / \mathrm{mL}$ for ENR to $121.71 \mathrm{ng} / \mathrm{mL}$ for CIP, while the $\mathrm{CC} \alpha$ values ranged from $110.58 \mathrm{ng} / \mathrm{mL}$ for ENR to $115.89 \mathrm{ng} / \mathrm{mL}$ for CIP. For determination of accuracy and precision (repeatability and reproducibility) of the method a blank milk samples were fortified with a mixture of FQs standards at three concentration levels ( $0.5 \mathrm{x}$ MRL, $1 \mathrm{x}$ MRL and $1.5 \mathrm{x}$ MRL). The MRL for ENR and CIP is $100 \mathrm{ng} / \mathrm{mL}$. The average recoveries for all three concentration levels varied from $88 \%$ to $109 \%$. Precision was evaluated by $\mathrm{CV}, \%$ (coefficients of variation). The $\mathrm{CV}$ for repeatability ranged from 5.23 to $20.38 \%$, while the $\mathrm{CV}$ for reproducibility ranged from $4.11 \%$ to $20.80 \%$. In the milk samples included in this study the residues of CIP and ENR above the MRL values weren't detected.

\section{Conclusion}

The LC-MS/MS method has been developed and successfully validated according to the EU requirements to determination of fluoroquinolone residues in milk. The method can be used in routine analyses of milk samples.

\section{References}

Alija, Gj., Hajrullai-Musliu, Z., 2016. A review of analytical methods for the determination of antibiotics residues in food of animal origin. Acta Medica Balkanica 1(2), 55-62.

Berendsen, B.J.A., 2013. LC-MS residue analysis of antibiotics, what selectivity is adequate? $\mathrm{PhD}$ thesis, Wageningen University, Wageningen, NL.

European Commission. Decision 2002/657/EC of 12 August 2002 implementing council directive 96/23/EC concerning the performance of analytical methods and interpretation of results.

Junza, A., Amatya, R., Perez-Burgos, R., Gokce, G., Grzelak, E., Barbosa, J., 2010. Residues of $\beta$-lactams and quinolones in tissues and milk samples. Confirmatory analysis by liquid chromatographymass spectrometry. Ovidius University Annals of Chemistry 21(2), 109-122.

Uzunov, R., Hajrulai-Musliu, Z., Stojkovski, V., Dimitrieska-Stojkovic, E., Stojanovska-Dimzoska, B., Sekulovski, P., Jankuloski, D., 2019. Development and validation of LC-MS/MS method for determination of ten beta agonists in bovine urine. Kafkas Univ. Vet. Fak. Derg. 25(1), 55-60.

Maced. Pharm. Bull. 66 (Suppl 1) 177 - 178 (2020) 